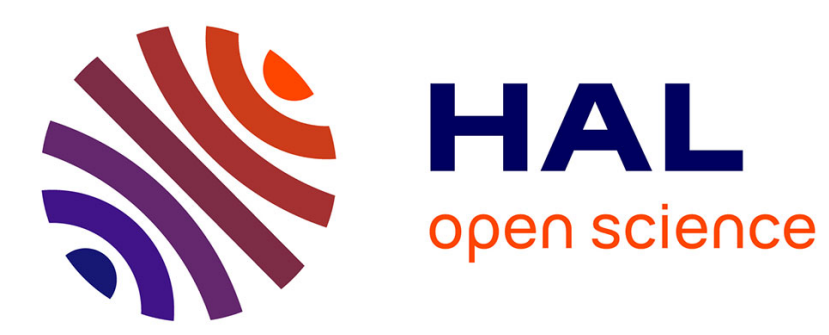

\title{
Optical properties of ferroelectrics. digressions from phenomenological theory
}

\author{
A.T. Anistratov
}

\section{To cite this version:}

A.T. Anistratov. Optical properties of ferroelectrics. digressions from phenomenological theory. Revue de Physique Appliquée, 1972, 7 (2), pp.77-79. 10.1051/rphysap:019720070207700 . jpa-00243607

\section{HAL Id: jpa-00243607 https://hal.science/jpa-00243607}

Submitted on 1 Jan 1972

HAL is a multi-disciplinary open access archive for the deposit and dissemination of scientific research documents, whether they are published or not. The documents may come from teaching and research institutions in France or abroad, or from public or private research centers.
L'archive ouverte pluridisciplinaire HAL, est destinée au dépôt et à la diffusion de documents scientifiques de niveau recherche, publiés ou non, émanant des établissements d'enseignement et de recherche français ou étrangers, des laboratoires publics ou privés. 


\title{
REVUE DE PHYSIQUE APPLIQUÉE
}

Supplément au « Journal de Physique *

\section{OPTICAL PROPERTIES OF FERROELECTRICS. DIGRESSIONS FROM PHENOMENOLOGICAL THEORY}

\author{
A. T. ANISTRATOV \\ L. V. Kirensky Institute of Physics, Academy of Sciences USSR Siberian Department, \\ Krasnoyarsk 36, USSR
}

(Reçu le 8 novembre 1971, révisé le 3 janvier 1972)

\begin{abstract}
Résumé. - Les variations de la biréfringence en fonction de la température ont été mesurées sur les cristaux de $\left(\mathrm{NH}_{4}\right)_{2} \mathrm{SO}_{4},\left(\mathrm{NH}_{4}\right)_{2} \mathrm{BeF}_{4}$ et $\left(\mathrm{CH}_{3} \mathrm{NH}_{3}\right) \mathrm{Al}\left(\mathrm{SO}_{4}\right)_{2} .12 \mathrm{H}_{2} \mathrm{O}$ et une estimation des constantes photoélastiques a été donnée.

Nous avons étudié le comportement en température des caractéristiques électro-optiques et diélectriques. Nous avons montré que les changements spontanés de la biréfringence qui apparaissent ne sont pas proportionnels à $\boldsymbol{P}_{\mathrm{s}}^{2}$. Une discussion de l'influence de la polarisation spontanée $\boldsymbol{P}_{\mathrm{s}}$ et de la déformation spontanée sur les anomalies des constantes lors des transitions ferroélectriques est abordée ici.
\end{abstract}

Abstract. - Temperature dependences of birefringence were measured in $\left(\mathrm{NH}_{4}\right)_{2} \mathrm{SO}_{4}$, $\left(\mathrm{NH}_{4}\right)_{2} \mathrm{BeF}_{4}$ and $\left(\mathrm{CH}_{3} \mathrm{NH}_{3}\right) \mathrm{Al}\left(\mathrm{SO}_{4}\right)_{2} .12 \mathrm{H}_{2} \mathrm{O}$ crystals and the photoelastic constants of the crystals were estimated. The temperature behaviour of electro-optical and dielectric characteristics was investigated. It is shown that spontaneous changes of birefringence appearing are disproportional to $\boldsymbol{P}_{\mathrm{s}}^{2}$. The contributions of $\boldsymbol{P}_{\mathrm{s}}$ and spontaneous deformation into optical constants anomalies at ferroelectric transitions are discussed.

It is well known that in addition to the usual thermo-optical variations optical constant changes take place at ferroelectric phase transitions [1]-[3]. These changes can be considered phenomenologically as a result of spontaneous electro-optic effect [4]. Its components are linear and (or) quadratic electrooptic effects of paraelectric phase, and an elastooptic effect due to spontaneous deformation accompanying a $P_{\text {s }}$ appearance. Temperature dependences of optical constants of $\mathrm{KDP}, \mathrm{BaTiO}_{3}$, TGS [5]-[7] and many other ferroelectrics were adequately described on this basis. However it was noticed many times [8]-[10] that in such crystals as

$$
\mathrm{PbTiO}_{3}, \quad \mathrm{Ca}_{2} \mathrm{Sr}\left(\mathrm{C}_{2} \mathrm{H}_{5} \mathrm{COO}\right)_{6}
$$

and $\mathrm{NaNO}_{2}$ the birefringence changes below $T_{\mathrm{c}}$ appeared to be disproportional to $P_{s}^{2}$, as it follows from this description. Up to now no satisfactory explanation of unusual $\Delta n\left(P_{\mathrm{s}}^{2}\right)$ dependences in these crystals was suggested. Similar optical constant behaviour was observed recently by the author in $\left(\mathrm{NH}_{4}\right)_{2} \mathrm{SO}_{4}$ (AS), $\left(\mathrm{NH}_{4}\right)_{2} \mathrm{BeF}_{4}(\mathrm{AFB})$ and

$$
\left(\mathrm{CH}_{3} \mathrm{NH}_{3}\right) \mathrm{Al}\left(\mathrm{SO}_{4}\right)_{2} .12 \mathrm{H}_{2} \mathrm{O} \text { (MASD) }
$$

near the first order transitions at $T_{\mathrm{c}}=223,5^{\circ}, 179,6^{\circ}$ and $177^{\circ} \mathrm{K}$ respectively [3].

In an effort to determine the main reasons of this unusual behaviour the spontaneous birefringence changes in AS, AFB and MASD crystals were measured within a wide temperature range, including $T_{\mathrm{c}}$. Photoelastic constants of the crystals were also estimated. The temperature dependences of a quadratic electrooptic effect in paraelectric phases were investigated. Dielectric properties $\left(\varepsilon, P_{\mathrm{s}}\right)$ were measured simultaneously with electro-optic experiments on the same samples.

Birefringence measurements were made with a Berek compensator [11] on the samples where the light propagations coincided with [100], [010] and [001] in ortorhombic AS and AFB and $<100>$ directions in MASD crystals. Electro-optic experiments were carried out by the dynamic method [12] at a wavelength of $6328 \AA$. The outer electric field with the frequency of $800 \mathrm{cps}$ was applied along the polar directions of crystals.

For comparison purposes we shall discuss the results obtained on the ferroelectric cuts. Birefringence $\Delta n_{\mathrm{c}}$ of AS is linearly dependent on temperature 
above $T_{\mathrm{c}}$. A steplike change takes place at $T_{\mathrm{c}}$ and then $\Delta n_{\mathrm{c}}$ changes non-linearly. On the other hand, a $P_{\mathrm{s}}$ - value occurs abruptly at $T_{\mathrm{c}}$ and does not change below $T_{\mathrm{c}}$ [13]. In contrast, the birefringence $\Delta n_{\mathrm{b}}$ of AFB is linear with temperature both above and below $T_{\mathrm{c}}$. These results are in agreement with Strukov's data [14]. $\delta\left(\Delta n_{\mathrm{b}}\right)$ dependence versus $P_{\mathrm{s}}^{2}$ is shown in figure $1 a$. The birefringence of MASD sharply appears at $T_{\mathrm{c}}$ and non-linearly changes below $T_{\mathrm{c}} . \delta(\Delta n)$ versus $P_{\mathrm{s}}^{2}$ of MASD is shown in figure $1 b$.
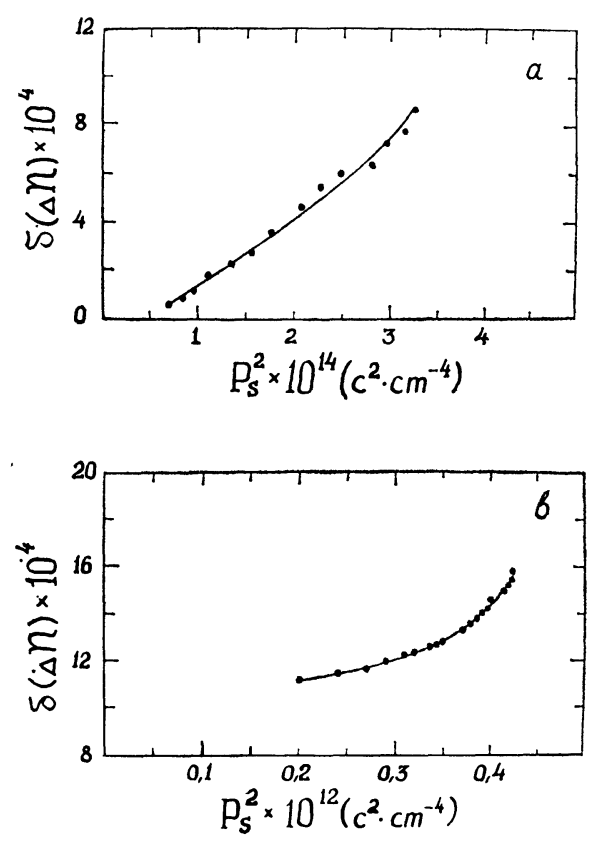

Fig. 1. - The birefringence changes versus $P_{\mathrm{s}}^{2}$. a) AFB, b) MASD.

The coefficients of a quadratic electro-optic effect $\mathrm{L}_{\mathbf{i j}}^{\boldsymbol{X}, \boldsymbol{T}}$ [12], connecting the birefringence changes with the outer electric field squared, have anomalies for AS, AFB and MASD crystals near $T_{\mathrm{c}}$. These anomalies follow the dielectric ones. Because of this the $\mathrm{M}_{\mathrm{ij}}^{X, T}$ [12], connecting the birefringence changes with the polarization squared, are practically independent of the temperature. The values of $\mathbf{M}_{\mathbf{i} \mathbf{j}}^{\boldsymbol{X}, \boldsymbol{T}}$ are lgiven in table $\mathbf{I}$.

The estimation of the elasto-optic constants was made from paraelectric phase data. $\Delta n(T)$ dependences were used for AS and AFB crystals [7], [13], $n_{0}(T)$ dependence for MASD was measured by the Chaulnes method [15]. The mean values of $\bar{p}_{\mathbf{i j}}^{\boldsymbol{P}, \boldsymbol{T}}$ constants were derived (table 1 ).

By knowing the $\mathbf{M}_{\mathrm{ij}}^{X, T}$ values, the components of birefringence changes due to the spontaneous electro-optic effect could be estimated at $T_{\mathrm{c}}$ for the crystals investigated. The calculated values $\delta(\Delta n)$ and experimental ones are also given in table $\mathrm{I}$. A comparison of these values shows that the electro-optic contribution to the jumps of the birefringence at $T_{\mathrm{c}}$ is negligible for these crystals. These evident discrepancies from the phenomenological theory propositions can be explained by the following considerations.

According to phenomenological theory all spontaneous changes of the optical properties are connected only with the $P_{\mathrm{s}}$ appearance [4]. The spontaneous deformation in this theory is the result of electromechanical coupling. In other words, it is suggested that the spontaneous deformation of AS, AFB and MASD crystals is determined only by electrostrictive constants of paraelectric phases. However by X-ray and electromechanical measurements [16]-[18] it was shown that the lattice distortions of AS and MASD crystals below $T_{\mathrm{c}}$ could not be explained by the electrostriction. As for AFB crystal, the deformation could not be defined by electrostriction in this case because this transition is ruled by another transition parameter other than $P_{\mathrm{s}}[19]\left(^{*}\right)$. It was the spontaneous deformation behaviour that limited the field of uses for the theory considered. Optical constant anomalies of AS, AFB and MASD are determined mainly by the elasto-optic effect. Its contribution to birefringence changes could be estimated from thermal expansion [16], [17] and photoelasticity data.

\section{TABLE I}

Electro-optic and elasto-optic constants of AS, AFB and MASD crystals

\begin{tabular}{|c|c|c|c|}
\hline Crystal & AS & AFB & MASD \\
\hline $\mathbf{M}_{\mathrm{ij}}^{X, T} \times 10^{12} \mathrm{esu}$ & $n_{2}^{3} \mathrm{M}_{23}-n_{1}^{3} \mathrm{M}_{13}=17.0$ & $n_{3}^{3} \mathrm{M}_{32}-n_{1}^{3} \mathrm{M}_{12}=6.0$ & $n_{0}^{3}\left(\mathrm{M}_{31}-\mathrm{M}_{21}\right)=20.0$ \\
\hline $\mathrm{p}_{\mathrm{ij}}^{P, T}$ & $\mathrm{p}_{2 \mathrm{i}}-\mathrm{p}_{1 \mathrm{j}}=0.05$ & $\mathrm{p}_{3 i}-\mathrm{p}_{1 \mathrm{j}}=0.14$ & $\mathrm{p}_{1 \mathrm{i}}=0.65$ \\
\hline$P_{\text {So }} \times 10^{6} \mathrm{c} \cdot \mathrm{cm}^{-2}$ & 0.25 & $0.065[14]$ & 0.45 \\
\hline$\delta(\Delta n)_{T_{\mathrm{c}}}^{\mathrm{calc}}$ & $0.5 \times 10^{-5}$ & $1.0 \times 10^{-7}$ & $2.0 \times 10^{-5}$ \\
\hline$\delta(\Delta n)_{T_{\mathrm{c}}}^{\text {exper }}$ & $1.0 \times 10^{-3}$ & $5.0 \times 10^{-5}$ & $1.1 \times 10^{-3}$ \\
\hline
\end{tabular}

(*) According to [19] the phase transition in AFB is concerned with the effects of the crystal lattice rebuilding which is described by the parameter $\eta$. This parameter has non-vector transformation properties. A $\boldsymbol{P}_{\mathrm{s}}$-appearance in this case is explained by the crossed terms of the type $\eta^{2} \mathrm{P}$ in a thermodynamic potential expansion. 


\section{References}

[1] KÄNZIG (W.), Ferroelectrics and Antiferroelectrics, Academic Press Inc., New York, 1957.

[2] Fatuzzo (E.), Merz (W. I.), Ferroelectricity, NorthHolland Publishing Company, Amsterdam, 1967.

[3] Zheludev (I. S.), Phizika kristallicheskih dielektrikov, « Nauka », Moskow, 1968.

[4] Jona (F.), Shirane (G.), Ferroelectric crystals, Pergamon Press, Oxford-London-New York, Paris, 1962.

[5] Zwicker (B.), Scherrer (P.), Helv. Phys. Acta, 1944, 17, 346.

[6] Meyerhofer (D.), Phys. Rev., 1958, 112, 413.

[7] Ivanov (N. R.), Shuvalov (L. A.), Kristallografiya, 1966, 11, 614.

[8] Kobayashi (J.), Yamada (N.), Memoirs Waseda University, 1959, 23, 111.

[9] Kobayashi (J.), Yamada (N.), Journ. Phys. Soc. Japan, $1963,18,324$.
[10] Johnston (A. R.), NAKAMURA (T.), Solid State Commun, 1968, 6, 107.

[11] Melanholin (N. M.), Metody issledovaniya opticheskih svoistv kristallov, « Nauka », Moskow, 1970.

[12] Anistratov (A. T.), Aleksandrov (K. S.), Kristallografiya, 1967, 12, 459.

[13] Anistratov (A. T.), Martinov (V. G.), Kristallografiya, 1970, 15, 308.

[14] StruKov (B. A.), Kristallografiya, 1961, 6, 635, 780.

[15] Miller (A. R.), Journ. Opt. Soc. America, 1968, $58,428$.

[16] Hoshino (S.), Vedam (K.), Okaya (Y.), Pepinsky (R.), Phys. Rev., 1958, 112, 405.

[17] Kozhin (V. M.), Zaitseva (M. P.), Kristallografiya, $1969,14,344$.

[18] Zaitseva (M. P.), Zherebtsova (L. I.), VinograDovA (I. S.), Proc. Intern. Meeting Ferroelectricity, Prague, 1966, 1, 341.

[19] LevanyuK (A. P.), SANNIKov (D. G.), Zhurnal experim. $i$ teoretich. phiziki, 1968, 55, 256. 